\title{
Integrasi teknologi dalam pembelajaran: Upaya untuk beradaptasi dengan tantangan era digital dan revolusi industri 4.0
}

\author{
Afrianto Daud*, Ando Fahda Aulia, \& Nita Ramayanti \\ Universitas Riau \\ * afrianto.a@lecturer.unri.ac.id
}

\begin{abstract}
Abstrak. Era Revolusi Industri 4.0 telah membawa tantangan dan peluang baru untuk dunia pendidikan. Salah satu peluang itu adalah semakin terbukanya peluang bagi guru untuk mengintegrasikan teknologi ke dalam proses pembelajaran, sehingga hasil belajar bisa lebih efektif. Masalahnya adalah belum banyak guru yang memiliki kemampuan mengintegrasikan teknologi ke dalam kelas mereka. Terutama guru sekolah swasta dengan fasilitas terbatas. Program Pengabdian Kepada Masyarakat ini berusaha membantu guru memilki kemampuan ini dengan memperkenalkan penggunaan Google Apps For Education, seperti Google Classroom dan Google Hangout (Youtube Live) untuk Pembelajaran. Selain itu, guru juga dilatih dengan kemampuan video editing yang bisa mereka gunakan untuk pembuatan video pembelajaran. Kegiatan dilakukan dalam bentuk workshop kepada para guru di SMP Juara Pekanbaru. Ini adalah sekolah gratis di bawah managemen lembaga zakat Indonesia. Mayoritas siswanya adalah anakanak miskin. Setelah workshop, guru juga dibimbing dalam pelaksanaan/praktek di kelas. Kegiatan pengabdian saat ini pengabdian masih berjalan. Program berjalan relatif efektif. Hal ini terlihat dari perbanding hasi pre-tes dan pos-tes yang diberikan kepada peserta pelatihan. Empat orang $(36,4 \%)$ dari 11 peserta menyatakan memiliki kemampuan sangat baik dalam menggunakan Google Classroom, dan lima orang $(45,4 \%)$ dari 11 peserta menyatakan baik. Angka ini jauh berbeda dari hasil pre-tes yang menunjukkan bahwa $10(90,0 \%)$ dari 11 peserta menyatakan belum mengenal dan tidak mampu menggunakan aplikasi Google Classroom.
\end{abstract}

Kata kunci: teknologi dalam pembelajaran; era digital; revolusi industri 4.0; SMP juara

\begin{abstract}
The era of the Industrial Revolution 4.0 has brought new challenges and opportunities to education. One of them is the increasing opportunities for teachers to integrate technology into the learning process so that learning outcomes can be more effective. The problem is that not many teachers have the ability to integrate technology into their classrooms. This is especially the case for private school teachers with limited facilities. This Community Service Program seeks to help teachers equipped with this ability by introducing the use of Google Apps for Education, such as Google Classroom and Google Hangout for Learning. In addition, teachers are also trained with the video editing skills that they can use to make video-based learning media. The activity was carried out in the form of a workshop for teachers at Sekolah Juara Pekanbaru. This is a free school under the management of Indonesian Zakat Institution. The majority of students are coming from poor families. After the workshop, the teachers were also guided in the implementation/practice in the classroom. The program runs quite effectively. This can be seen from the comparison of the pre-test and the post-test given to the trainees. Four people (36.4\%) from 11 participants stated that they had the ability to use the Google Classroom at a very good level, and five people (45.4\%) were at a good level. This number is far different from the results of the pre-tests which showed that $10(90.0 \%)$ of the 11 participants stated that they were not familiar with and were unable to use the Google Classroom application.
\end{abstract}

Keywords: technology in learning; digital era; industrial revolution 4.0; SMP Juara

To cite this article: Daud, A., A. F. Aulia, \& N. Ramayanti. 2019. Integrasi teknologi dalam pembelajaran: Upaya untuk beradaptasi dengan tantangan era digital dan revolusi industri 4.0. Unri Conference Series: Community Engagement 1: 449-455 https://doi.org/10.31258/unricsce.1.449-455

(C) 2019 Authors

Peer-review under responsibility of the organizing committee of Seminar Nasional Pemberdayaan Masyarakat 2019 


\section{PENDAHULUAN}

Guru adalah kunci dan pemain utama dalam menjalankan proses pendidikan. Konten kurikulum yang sempurna, fasilitas atau infrastrktur pendidikan yang lengkap, aturan main atau perangkat hukum yang canggih tidak akan banyak memberi pengaruh terhadap keberhasilan pendidikan jika tidak ditopang oleh kesiapan para guru di lapangan (Palmer, 1998). Karena alasan ini, adalah tepat jika pemerintah Indonesia memberikan perhatian khusus terhadap usaha profesionalisasi pendidik dalam sepuluh tahun terakhir, terutama setelah berlakunya UU 14/2005 tentang guru dan dosen. Menjadi guru profesional kemudian menjadi isu penting semua stakeholders pendidikan Indonesia setelah itu.

Saat ini guru tidak hanya dihadapkan pada tingginya tuntutan masyarakat terhadap kualitas pembelajaran, guru juga berhadapan dengan perkembangan teknologi yang demikian cepat di dunia sekitar. Salah satunya adalah bahwa hari ini pendidikan sedang berada di era revolusi industri 4.0. Salah ciri penting RI 4.0 adalah terjadinya revolusi digital di tengah masyarakat. Disebut revolusi digital karena terjadinya proliferasi komputer dan otomatisasi pencatatan di semua bidang. Dampak atau turunan logisnya adalah terjadinya apa yang disebut dengan era disrupsi teknologi. Industri 4.0 dikatakan era disrupsi teknologi karena otomatisasi dan konektivitas di sebuah bidang akan membuat pergerakan dunia industri dan persaingan kerja menjadi tidak linear.

Dunia saat ini berkembang dan berubah dengan cepat. Oleh karena itu, penting bagi guru untuk terus memperbarui dan terbiasa dengan setiap perkembangan dalam teknologi informasi dan komunikasi (TIK). Keakraban ini akan memungkinkan para guru untuk menggunakan teknologi untuk meningkatkan pengajaran mereka di kelas. Ini juga karena tantangan yang dihadapi oleh guru saat ini mungkin sama sekali berbeda dari guru di masa lalu (Afrianto, 2018; Isjoni et al., 2019). Kebutuhan dan perilaku siswa terkait dengan penggunaan teknologi, misalnya, berbeda dari apa yang guru lihat bertahun-tahun yang lalu. Oleh karena itu, guru hari ini tidak dapat mendekati siswa mereka dengan cara yang dulu dilakukan oleh guru lama mereka. Seperti kata Chamberlain (2012) dalam Neumann (2014), "Pendidikan berkembang pesar karena dampak Internet. Kita tidak dapat mengajar siswa kita dengan cara yang sama seperti ketika kita diajarkan. Diperlukan perubahan pendekatan untuk melibatkan siswa dalam proses pembelajaran."

Kekhawatiran Chamberlain jelas karena revolusi teknologi dalam pendidikan telah membawa tantangan baru dan peluang baru bagi para pendidik di seluruh dunia. Teknologi ini hanya menciptakan peluang bagi guru untuk mempercepat pembelajaran siswa, tetapi juga dapat menantang guru bagaimana memanfaatkan siswa sebagai salah satu sumber belajar yang penting. Karena keakraban mereka dengan perangkat teknologi tinggi, ada kemungkinan bahwa beberapa siswa saat ini dapat mengakses pelajaran tertentu jauh sebelum guru mereka materi di kelas. Anak-anak zaman sekarang memang luar biasa dalam arti kemampuan mereka untuk mengeksplorasi teknologi. Ini relevan dengan istilah yang pertama kali diciptakan dan dipopulerkan oleh seorang konsultan pendidikan, Prensky (2001), mengatakan bahwa mayoritas siswa saat ini dianggap sebagai 'penduduk asli digital' (digital native generation). Ini merujuk pada fakta bahwa mereka telah terbiasa dengan perangkat elektronik apa pun, termasuk penggunaan ponsel dan internet sejak mereka masih kecil. Oleh karena itu, para guru seharusnya tidak ketinggalan siswa mereka dalam menggunakan teknologi ini.

Selain itu, setidaknya ada dua alasan utama mengapa seorang pendidik perlu memanfaatkan teknologi digital untuk pengajarannya. Pertama, dari sudut pandang kepraktisan, ada beberapa kondisi ketika guru secara fisik tidak dapat menghadiri ruang kelas tradisional mereka. Mungkin karena mobilitas mereka yang tinggi atau tugas mereka di luar kota. Beberapa dosen universitas, misalnya, mungkin sangat aktif di luar kampus seperti menghadiri konferensi di luar negeri atau melakukan tugas atau kegiatan akademik lainnya di luar kota. Untuk alasan ini, mereka harus meninggalkan kelas mereka dan para siswa harus menunggu sampai mereka kembali ke kampus. Ini jelas tidak adil bagi mahasiswa, terutama jika dosen harus pergi cukup lama.

Beberapa situasi tak terduga seperti bencana alam mungkin juga telah menghambat ruang kelas tradisional. Ketika masalah kabut menyerang Pulau Sumatera tiga tahun lalu, misalnya, semua sekolah dan universitas di provinsi Riau ditutup selama lebih dari dua bulan. Dalam konteks ini, kami berpendapat bahwa jika sekolah, universitas, guru, dan dosen telah terbiasa dengan perangkat teknologi pembelajaran online, seperti Google Apps For Education (GAFE), mereka akan dapat menjaga kelas mereka melalui ruang kelas virtual terlepas dari semua kendala.

Selanjutnya, dari sudut pandang teoritis, memperkenalkan ruang kelas online atau virtual akan membawa beberapa keuntungan untuk proses belajar mengajar. Beberapa penelitian menunjukkan bahwa lingkungan belajar virtual dapat kondusif untuk pembelajaran, karena pembelajaran online muncul untuk meningkatakan kesadaran diri siswa, dan memotivasi mereka untuk belajar lebih mandiri, dan kemudian bisa meningkatkan 
capaian pembelajaran mereka (misalnya Bradley \& Lomicka, 2000; Wallace, 1999; Carnevale , 2003; Roed, 2003 dikutip dalam Lewandowski, 2015).

Kegiatan kelas virtual ini juga dapat dianggap sebagai cara bagi guru untuk melakukan blended learning (Whittaker \& Tomlinson, 2013). Dalam konteks Pengajaran Bahasa Inggris (ELT), 'blended learning' adalah istilah yang paling umum digunakan untuk merujuk pada kombinasi pengajaran tatap muka dengan teknologi komputer (aktivitas / bahan online dan offline). Oleh karena itu, itu akan menjadi ide yang baik bagi guru untuk memiliki ruang kelas virtual sebagai tambahan atau variasi ke mode pengajaran tradisional mereka selama kalender akademik mereka. Dalam praktiknya, terlepas dari beberapa alasan praktis seperti disebutkan di atas, untuk melakukan blended learning ini, para guru harus merencanakan terlebih dahulu untuk memiliki beberapa ruang kelas virtual dengan menggunakan beberapa aplikasi yang tersedia. Variasi memang ide yang baik dalam hal mempertahankan minat siswa dan memungkinkan mereka untuk memiliki pengalaman belajar yang baru.

Penting bagi guru untuk menguasai beberapa aplikasi tertentu sehingga mereka bisa mempertahankan minat siswa untuk mau belajar melalui media internet. Mereka juga perlu mengusai bagaimana membuat konten yang menarik, mampu menyampaikan pesan baik dalam bahasa verbal, gambar maupun menggunakan audio yang telah diproduksi untuk menjadi bahan ajar. Pesan yang efektif adalah ketika guru mampu menyampaikan pesan dengan tepat dan dapat dipahami oleh siswa dengan baik.

Untuk mendukung para pendidik di seluruh dunia, dalam enam tahun terakhir ini sebagai bagian dari program Google Apps for Education (GAFE). Google telah merilis banyak aplikasi yang dapat digunakan oleh para guru untuk meningkatkan pengajaran dan pembelajaran berbasis teknologi informasi (TI) mereka. Aplikasi ini sekarang tersedia secara gratis. Ini termasuk Gmail, Google Doc, Google Drive, Google Sheet, Google Google Talk, Google Classroom, Google Hangouts on Air, dan banyak lainnya. Makalah ini melaporkan bagaimana efektivitas pelatihan penggunaan salah satu aplikasi GAFE - Google Classroom untuk para guru di salah satu sekolah di kota Pekanbaru.

\section{Masalah}

Beberapa masalah yang sering muncul di lapangan dalam konteks penggunaan Information Comunication Technology (ICT) adalah: Pertama kurangnya SDM (Sumber Daya Manusia) guru yang menguasai ICT. Pemakaian ICT di sini tentu tidak hanya sekedar memiliki laptop, komputer dan sejenisnya. Tetapi, bagaimana seorang guru bisa memaksimalkan perangkat ICT ini untuk proses pembelajaran. Beberapa penelitian menunjukkan bahwa masih banyak guru kita yang gagap teknologi di sekolah.

Kedua, rendahnya kesadaran pentingnya ICT dalam pembelajaran. Sebagian guru masih memandang bahwa ICT hanyalah pilihan yang bisa digunakan ataupun tidak. Mereka menggap bahwa ICT tak berpengaruh banyak terhadap efektivitas pembelajaran di kelas. Kurangnya pemanfaatan ICT ini dalam proses pembelajaran di sekolah bisa jadi terkait masih rendahnya dukungan pihak sekolah dan pemerintah terhadap peningkatan kemampuan guru dalam mengintegrasikan pembelajaran mereka dengan teknologi. Padahal peningkatan kualitas pendidikan tidak bisa hanya dengan memperbaiki infrastukur dalam pembangunan fisik saja melainkan juga harus melihat aspek SDM, salah satunya adalah guru. Guru yang berkualitas adalah kunci dalam menunjang perbaikan kualitas pendidikan.

Peningkatan kapasitas guru tentu saja tidak hanya dilakukan dengan melakukan pembekalan tentang silabus dan kurikulum saja. Melainkan peningkatan kualitas guru dalam teknologi pembelajaran juga menjadi salah satu indikator penting. Guru pada saat ini harus menjadi guru yang melek teknologi. Jika saat ini kebanyakan guru masih saja berfokus pada penggunaan Ms. Power Point contohnya, maka saat ini sudah saatnya guru mengupdate ke level yang lebih tinggi, salah satunya adalah penggunaan Google Apss for Education yang tengah marak diperbincangkan saat ini. Google Apps for Education saat ini telah banyak dipergunakan oleh berbagai sekolah dan perguruan tinggi di Indonesia karena telah terbukti memiliki banyak manfaat dalam proses pembelajaran.

Memperhatikan beberapa fenomena di atas, kami melakukan kegiatan Pengabdian Kepada Masyarakat.. Sasaran kegiatan pengabdian yaitu guru SMP Juara Pekanbaru. Pengabdian dilakukan dalam bentuk pelatihan dan pendampingan kepada para guru di sekolah ini dalam mengintegrasikan proses pembelajaran mereka dengan memanfa'atkan teknologi komunikasi, seperti pemanfaatan beberapa aplikasi di Google Apps For Education, seperti Google Classroom, Google Doc, Google Sheet, Google Drive, dan Youtube Live untuk presentasi online. 


\section{METODE}

Untuk menjawab masalah yang disebutkan di atas, kami melakukan kegiatan pengabdian kepada masyarakat melalui beberapa metode:

1. Workshop

Workshop dilakukan kepada seluruh guru SMP Juara. Workshop ini dijadwalkan berlangsung pada dua sesi. Sesi pertama sudah terlaksana dalam bentuk pelatihan setengah hari terkait pengenalan dan praktek penggunaan Google Classroom. Workshop sesi kedua akan dilaksanakan dengan materi pembuatan media pembelajaran berbasis video editing dalam rangka pengisian konten Google Classroom.

2. Pendampingan

Pendampingan dilakukan di dalam kelas ketika guru menggunakan aplikasi dengan siswa. Pendampingan ini dilakukan berkolaborasi dengan mahasiswa Kuliah Kerja Nyata (KKN) Terintegrasi Universitas Riau. Mereka membantu guru selama penggunaan aplikasi di dalam kelas jika guru mengalami masalah.

3. Pre-tes dan Post-tes.

Tes dilakukan untuk mengukur efektivitas dan feedback guru terhadap workshop. Tes dilakukan dalam bentuk pengisian kuesioner yang terdiri dari beberapa pertanyaan tertutup dan terbuka (lihat lampiran). Efektivitas program dianalisa dengan membandingkan jawaban peserta sebelum pelatihan dan setelah pelatihan.

\section{PEMBAHASAN}

Bagian ini akan membahas langkah-langkah pengintegrasian teknologi Google Classroom oleh guru ke dalam kelas, serta melihat bagaimana efektivitas pelatihan yang dilakukan kepada guru SMP Juara sebagai bentuk kegiatan pengabdian kepada masyarakat.

\section{Prosedur Penggunaan Google Classroom}

Ada rincian kegiatan atau prosedur penggunaan google classroom sebagai platform pembelajaran online adalah sebagai berikut.

\section{Tahap 1: Mendaftar di Akun Google.}

Sebelum memulai, ada beberapa masalah teknis yang perlu dipastikan guru terlebih dahulu. Jika guru memiliki PC dengan konfigurasi terbaru yang terhubung ke jaringan internet yang dapat diandalkan, itu akan menjadi suasana kelas yang ideal untuk menggunakan Google Classroom untuk pembelajaran. Jika tidak, guru harus mengingatkan siswa untuk membawa laptop atau perangkat lain sendiri, seperti iPad atau ponsel pintar mereka ke dalam kelas. Hanya dengan perangkat ini, mereka dapat mengikuti semua kegiatan yang telah direncanakan dengan baik dalam kegiatan di dalam kelas atau di rumah.

Selain memiliki komputer dengan konfigurasi terbaru, guru dan siswa juga perlu memiliki koneksi internet berkecepatan relatif tinggi. Koneksi internet yang andal dan penyediaan daya sangat penting untuk penggunaan Google Classroom ini. Selain itu, guru perlu memiliki sumber daya alternatif untuk memastikan transmisi arus listrik berlangsung terus menerus bahkan selama pemadaman listrik.

Hal penting pertama yang perlu guru dan siswa lakukan untuk dapat menggunakan Google Classroom adalah memastikan bahwa semua orang di dalam kelas sudah memiliki akun Google atau Gmail. Guru dan siswa dapat menggunakan Gmail pribadi atau akun bisnis mereka untuk log in. Ini seperti paspor untuk mengakses semua Aplikasi Google, termasuk Google Classroom. Jika guru atau siswa belum memilikinya, mereka dapat mendaftar secara gratis. Mendaftar adalah proses yang mudah. Setelah memiliki akun Google, setia orang dapat mengakses dan menggunakan semua aplikasi Google di ponsel cerdas atau tablet mereka.

\section{Tahap 2. Install Aplikasi Google Classroom}

Jika siswa tidak bekerja melalui PC atau laptop, guru bisa meminta siswa untuk menginstal aplikasi Google Classroom di gawai mereka. Setelah setiap orang siap dengan aplikasi yang terinstal, guru kemudian dapat mengundang siswanya untuk bekerja dengannya melalui Kelas Google.

Tahap 3. Membuat Kelas

Google Classroom memungkinkan guru untuk membuat area kelas online di mana mereka dapat mengelola semua dokumen yang dibutuhkan siswa mereka. Guru dapat membuat tugas dari dalam kelas, yang 
diselesaikan siswa mereka dan diubah menjadi dinilai. Dalam membuat kelas guru harus dapat memastikan nama pelajaran, waktu dan siswa yang akan di invite untuk memasuki kelas sehingga manajemen kelas dalam google classroom akan baik nantinya, hal ini dikarenakan banyaknya pelajaran yang akan dikelola nantinya.

Ikuti langkah-langkah ini untuk membuat kelas:

1. Buka peramban web dan buka https://classroom.google.com. Guru harus masuk dengan akun gmail mereka.

2. Pada layar Selamat Datang, klik tanda plus di bagian atas dan pilih Buat Kelas (lihat Gambar 1).

3. Di kotak dialog Buat Kelas, ketikkan Nama Kelas dan Bagian.

4. Klik Buat.

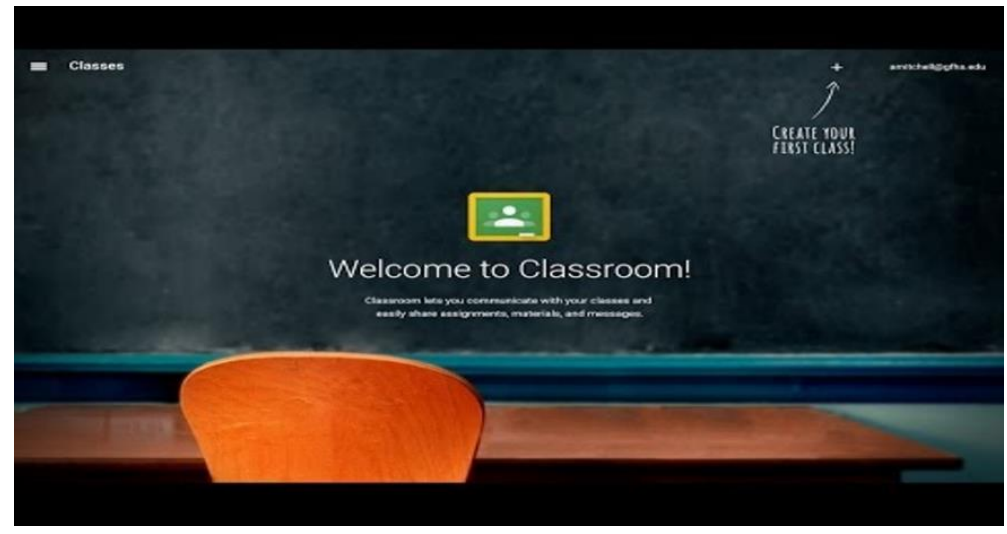

Gambar 1. Tampilan Google Classroom

Tahap 4. Mengeksplorasi Google Classroom

Setelah guru membuat kelas dan mengundang siswa ke dalam kelas google, maka guru bisa mengeksplorasi kelasnya untuk berbagai macam keperluan. Guru bisa mengelola kelas secara virtual. Tidak hanya untuk satu dua kelas. Guru bisa membuat kelas sebanyak mungkin, tergantung berapa mata pelajaran yang dia ajar dalam satu sesi tertentu (lihat Gambar 2).

$$
\equiv \text { Google Classroom }
$$
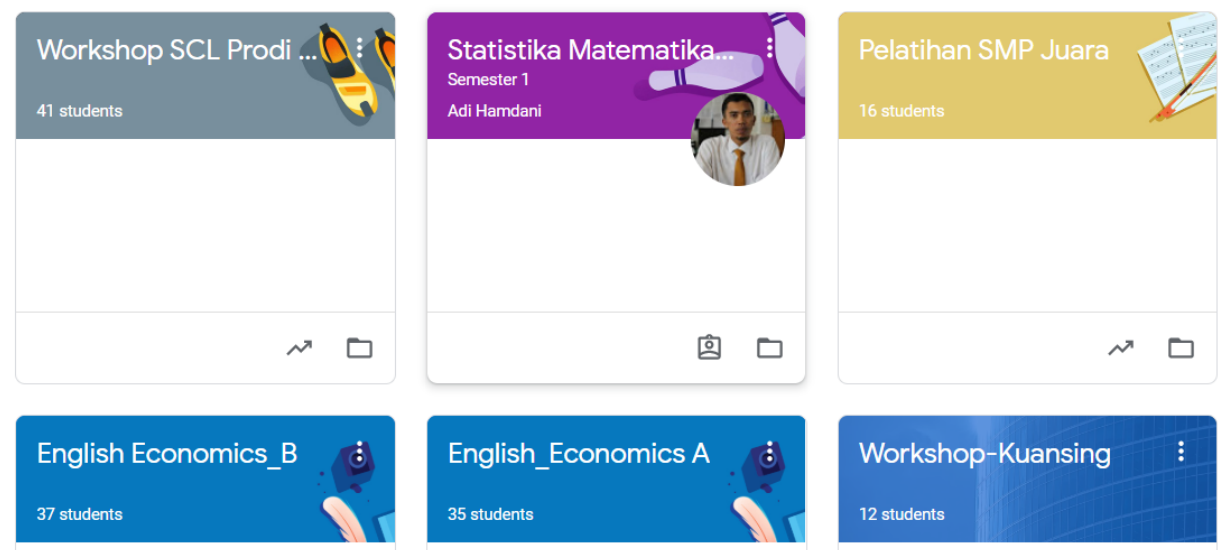

Gambar 2. Tampilan Folder Google Classroom

Melalui Google Classroom. Guru bisa membuat pengumuman, mengupload materi atau bahan ajar, membuat tugas, memberi feedback terhadap tugas siswa, dan juga memberi nilai. Semua aktivitas akan tersimpan dengan baik dalam server google, karena perangkat Google Classroom terkoneksi secara otomatis ke Google Drive. Dengan demikian, Google Classroom bisa juga dimanfaatkan untuk tempat penyimpanan portfolio pengajaran dan portfolio karya siswa. 


\section{Refleksi Pelaksanaan Pelatihan Googel Classroom di SMP Juara}

Selain melihat kemampuan penggunaan kelas google oleh guru SMP Juara, ada beberapa poin umum yang ditanyakan dalam angket yang didistribusikan sebelum dan setelah pelatihan. Diantaranya terkait tentang pendapat mereka tentang pentingnya pembelajaran yang dimoderasi internet, frekuensi akses guru terhadap internet, persepsi guru terhadap google classroom, dan pengetahuan mereka tentang google classroom sebelum dan setelah pelatihan.

Data angket menunjukkan bahwa semua peserta (100\%) mengganggap penting penggunaan internet dalam memoderasi proses pembelajaran di sekolah saat ini. Dalam hal akses guru terhadap internet, mayoritas guru (72,7 \%) mengakses internet sekitat 3-5 jam sehari. Hanya 1 guru yang menyampaikan bahwa dia mengakses internet kurang dari 1 jam sehari. Dengan demikian, dari sisi aksesibilitas guru terhadap jaringan internet cukup baik. Artinya tidak terdapat permasalahan terhadap aksesibilitas guru di SMA Juara.

Dalam hal pendapat guru terhadap pentingnya penggunaan google classroom untuk pembelajaran virtual, data angket menunjukkan bahwa terjadi kenaikan persentase jumlah peserta yang menyatakan sangat setuju dengan pernyataan bahwa google classroom merupakan salah satu metode pembelajaran yang efektif untuk dapat digunakan dalam proses belajar mengajar. Dalam angket pre-tes, 5 orang $(45,4 \%)$ dari 11 peserta menyatakan sangat setuju. Jumlah ini meningkat menjadi 9 orang $(81,8 \%)$ dari 11 peserta yang menyatakan sangat setuju. Ini berarti bahwa pelatihan yang dilakukan telah membantu mengubah persepsi mereka tentang pentingnya penggunaan google classroom.

Untuk mengecek efektivitas pelatihan dalam peningkatan kemampuan guru dalam menggunakan google classroom, setelah pelatihan peserta juga diminta menjawab pertanyaan poin terkait ini. Hasilnya mayoritas peserta menyatakan bahwa kemampuan mereka dalam penggunaan Google Classroom berada dalam kategori baik $(45,4 \%)$, dan sebagian lagi bahkan menjawab sangat baik $(36,4 \%)$. Namun demikian, ada dua orang peserta $(18,2 \%)$ yang menyatakan tidak baik. Hal ini mengindikasikan bahwa sebagian peserta memerlukan pendampingan dan pelatihan lanjutan. Detail perbandingan data pre-tes dan pos-tes bisa dilihat dalam Tabel 1.

Tabel 1. Perbandingan Hasil Pre Tes dan Pos Tes Peserta Pelatihan

\begin{tabular}{|c|c|c|c|c|}
\hline \multirow[b]{2}{*}{ Pernyataan } & \multicolumn{2}{|c|}{ Pre-Tes } & \multicolumn{2}{|c|}{ Pos-Tes } \\
\hline & $\begin{array}{l}\text { Jumlah } \\
\text { (orang) }\end{array}$ & $\%$ & $\begin{array}{l}\text { Jumlah } \\
\text { (orang) }\end{array}$ & $\%$ \\
\hline \multicolumn{5}{|c|}{$\begin{array}{l}\text { Menurut saudara, apakah metode pembelajaran saat ini penting } \\
\text { sekali menggunakan media internet }\end{array}$} \\
\hline a. Sangat setuju & 11 & 100 & 11 & 100 \\
\hline \multicolumn{5}{|c|}{ Saya mengakses internet untuk pembelajaran dalam seminggu } \\
\hline a. $1-2$ jam & 2 & 18,2 & 2 & 18,2 \\
\hline b. 3-5 jam & 8 & 72,7 & 8 & 72,7 \\
\hline c. $>5$ jam & 1 & 9,1 & 1 & 9,1 \\
\hline
\end{tabular}

Google classroom merupakan salah satu metode pembelajaran

yang efektif untuk dapat digunakan dalam proses belajar

mengajar
a. Sangat setuju
$5 \quad 45,4$
9
81,8
b. Setuju
$4 \quad 36,4$
2
18,2
c. Ragu-ragu
$2 \quad 18,2$

Apakah saudara sudah pernah menggunakan google classroom
a. Belum pernah
10
90,9
2
18,2
b. Sudah pernah
10,1
81,8

Bagaimana kemampuan anda dalam menggunakan google

classroom
a. Sangat baik
$4 \quad 36,4$
b. Baik
$7 \quad 45,4$
c. Tidak baik
$2 \quad 18,2$

Selain berjalan cukup efektif, tantangan utama dalam penggunakan aplikasi ini adalah ketersediaan perangkat pendukung, seperti gadget, laptop/PC yang terkoneksi ke internet. Jaringan internet yang lelet atau 
listrik yang hidup mati tentu akan mengurangi efektifitas pemakaian aplikasi oleh guru. Lebih dari itu, sekolah perlu membuat terobosan baru atau setidaknya memikir ulang apakah pelarangan membawa smartphone ke sekolah masih relevan, mengingat pentingnya digitalisasi pendidikan saat ini. Setidaknya sekolah perlu membuat kebijakan kebolehan terbatas penggunaan smartphone di dalam kelas, dengan aturan-aturan tertentu.

\section{KESIMPULAN}

Secara umum bisa disimpulkan bahwa program pengabdian kepada masyarakat ini berjalan cukup baik. Hal ini terlihat dari antusiasme guru dan sekolah dalam mengikuti kegiatan ini. Data pre-test dan post-test juga mengungkap bahwa pelatihan telah berkontribusi secara positif kepada guru dalam hal peningkatan pemahaman dan kemampuan mereka dalam menggunakan Google Apps For Education, khsusunya google classroom. Pelatihan perlu diteruskan pada sesi berikutnya mengenai pengenalan dan peningkatan kemampuan guru dalam membuat media pengajaran berbasis digital.

\section{UCAPAN TERIMA KASIH}

Ucapan terima kasih kepada kami sampaikan kepada Bapak Rektor dan Ketua Lembaga Penelitian dan Pengabdian kepada Masyarakat Universitas Riau yang telah memberikan bantuan dana kegiatan pengabdian kepada masyarakat di bawah skema Kegiatan Pengabdian Terintegrasi 2019 nomor kontrak 427/UN.19.5.1.3/PT.01.03/2019.

\section{DAFTAR PUSTAKA}

Afrianto, A. 2018. Being a Professional Teacher in the Era of Industrial Revolution 4.0: Opportunities, Challenges, and Strategies for Innovative Classroom Practices. English Language Teaching and Research 2(1).

Heggart, K. R., \& J. Yoo. 2018. Getting the Most from Google Classroom: A Pedagogical Framework for Tertiary Educators. Australian Journal of Teacher Education 43(3).

Isjoni, A. Daud, \& Azhar. 2019. Integrity and Performance of High School Teachers in Pekanbaru. Indonesian Journal of Economics, Social, and Humanities 1(1): 51-57. https://doi.org/10.31258/ijesh.1.1.5

Lewandowski, M. 2015. Creating virtual classrooms (using Google Hangouts) for improving language competency. Language Issues: The ESOL Journal 26(1): 37-42.

Neumann, C. 2014. 4 Important Reasons to Pair Mobile Devices with Interactive Whiteboards (And How to Do It!). https://www.tierneybrothers.com/AboutUs/NewsBlog/4ImportantReasonstoPairMobileDeviceswithInteractiveW hiteboardsandHowtoDoIt.aspx. Accessed on 26 November 2017.

Palmer, P. J. 1998. The courage to teach: exploring the inner landscape of a teacher's life. San Francisco, Calif: Jossey-Bass.

Prensky, M. 2001. Digital Natives, Digital Immigrants. On the Horizon 9(5).

Tomlinson, B \& C. Whittaker. 2013. Blended Learning in English Language Teaching: Course Design and Implementation. London: British Council. 